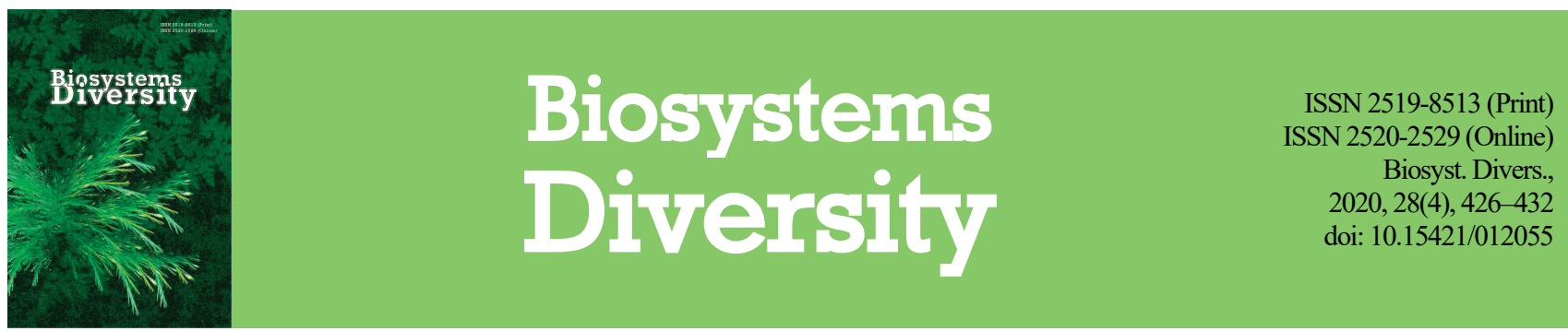

\title{
Effect of aluminium on redox-homeostasis of common buckwheat (Fagopyrum esculentum)
}

\author{
O. E. Smirnov*, A. M. Kosyan*, O. I. Kosyk*, L. M. Batsmanova*, \\ L. M. Mykhalska**, V. V. Schwartau**, N. Y. Taran* \\ *Taras Shevchenko National University of Kyiv, Kyiv, Ukraine \\ **Institute of Plant Physiology and Genetics, National Academy of Sciences of Ukraine, Kyiv, Ukraine
}

Article info

Received 15.10.2020

Received in revised form 19.112020

Accepted 21.11.2020

Taras Shevchenko National University of Kyiv,

Volodymyrska st., 64/13, Kyiv, 01601, Ukraine Tel.: +38-044-521-35-98 E-mail:

plantaphys@gmail.com

Institute of Plant Physiology and Genetics, National

Academy of Sciences of

Ukraine, Vasylkivska st

31/17, Kyiv, 03022, Ukraine.

Tel.: +38-044-257-90-18

E-mail:

VictorSchwartau@gmail.com

Smirnov, O. E., Kosyan, A. M., Kosyk, O. I., Batsmanova, L. M., Mykhalska, L. M., Schwartau, V. V., Taran, N. Y. (2020). Effect of aluminium on redox-homeostasis of common buckwheat (Fagopyrum esculentum). Biosystems Diversity, $28(4), 426-432$. doi:10.15421/012055

Common buckwheat is a significant culture in Ukraine, whose importance for food security has increased in recent decades. An important biological feature of buckwheat is the ability of the crop to grow on poor and especially acidic soils. Common buckwheat was sown in Ukraine on the area of 125,000 ha in 2020, mainly in the central part of the country and in the soil-climatic zone Polesie in the north of the country. At the same time, the area under buckwheat cultivation has been steadily decreasing in the last decade, which is due to the low profitability of cultivation on mainly acidic soils. The research was conducted in the field conditions during 2012-2018 in Kiev region, as well as in laboratory conditions. ICP analysis and biochemical methods were used. Yield of buckwheat on light soils of low fertility depends largely on the level of acidity of the soil. On acidic sod-podzolic soils with loam substrate, the aluminum content of the layer is $20-40 \mathrm{~cm}$ higher, compared to a layer of $0-20 \mathrm{~cm}$. This is probably one of the reasons why, when the concentration of aluminum in the soil profile is increased, the root system is located mainly in the upper layer of soil with a lower content of aluminum. In this case, the study of the mechanisms of resistance to the action of aluminum on acidic soils is an important component of the cost-effectiveness of crop production in the region. In acidic soils with $\mathrm{pH}<5.0$, phytotoxic aluminum $\left(\mathrm{Al}^{3+}\right)$ rapidly inhibits root growth and afterwards negatively affects water and nutrient uptake in plants. Acquiring phytotoxic capacities, in this connection $\mathrm{Al}$ ions affect a wide range of cellular and molecular processes, with a consequent reduction in plant growth. In most plant species, reactive oxygen species (ROS) production can also be induced by Al toxicity leading to oxidative damage of biomolecules and biological membranes. We have detected an accumulation of $\mathrm{Al}$ ions in leaf tissues of treatment plants after 10 days of exposure. Tissues of $F$. esculentum roots contained $155.4 \%$ of control level of $\mathrm{Al}$ and tissues of $F$. esculentum leaves $-186.2 \%$ of control level of $\mathrm{Al}$ ions. Significant intensification of $\mathrm{O}_{2}{ }^{-}$generation in roots and leaf tissues as a reaction to $\mathrm{Al}$ addition to nutrient solution was detected. Increase in antioxidant enzymes activities and non fixed products of lipids peroxidation was characterized as a biochemical defense reaction of $F$. esculentum over the 10 days of exposure to $\mathrm{Al}(50 \mu \mathrm{M})$. Thus, the results show that the action of $50 \mu \mathrm{M}$ of $\mathrm{Al}$ ions activated antioxidant enzymes - SOD and CAT and decreased oxidative processes, thus promotes pro/antioxidant balance of common buckwheat. These mechanisms of redox homeostasis can be triggers of morphological changes in buckwheat plants, which lead to increased crop resistance when growing on acidic soils with high aluminum content. Thus, the resistance of culture to acid soils may be associated with the possibility of increased accumulation of aluminum in the plant's tissues, as well as in changes in redox homeostasis with subsequent morphological changes, and primarily the formation of the root system in the top layer of soil with a reduced content of aluminum.

Keywords: acid soils; aluminium influence on plants; oxidative stress; aluminium resistance of plants.

\section{Introduction}

Common buckwheat is an important culture in Ukraine, whose significance for food security has increased in recent decades. It is accepted that buckwheat originated in the southwestern region of China, and subsequently became a widespread crop in the northern hemisphere of the Old World. Buckwheat is recognized as a health-promoting food and is cultivated in countries around the world. An important step towards achieving sustainable, healthy diets (FAO \& WHO, 2019) is promoting the use of food biodiversity, including traditional and local foods derived from nutrient - rich plants (Ohsawa et al., 2020).

An important biological feature of buckwheat is the ability of the crop to grow on poor, and especially acidic soils. Common buckwheat is sown in Ukraine on the area of 125 thousand ha in 2020, mainly in the central part, and in soil-climatic zone Polesie in the north of the country. At the same time, the area under buckwheat cultivation has been steadily decreasing in the last decade, which is due to the low profitability of cultivation on mainly acidic soils with high levels of aluminium (Al) content.
In this case, the study of the mechanisms of resistance to the action of $\mathrm{Al}$ acidic soils is an important component of the cost-effectiveness of crop production in the region.

$\mathrm{Al}$ is the most abundant metal and one of the most prevalent chemical elements in earth's crust after oxygen and silicon - about $7.5 \%$ by mass. For this reason $\mathrm{Al}$ can exist in several chemical forms, the mutual transformation and balance maintenance of which are strongly dependent on $\mathrm{pH}$ value. In $\mathrm{pH}$-neutral soils $\mathrm{Al}$ is inactivated primarily in mineral complexes - aluminosilicates (Haling et al., 2011). At $\mathrm{pH}<4.5$ in acidic soils, Al-containing complexes solubilize into ion form $\left(\mathrm{Al}^{3+}\right)$ which is characterized by high phytotoxic capacity (Silva, 2012). Al toxicity is one of the major limitations that inhibit plant growth, development and productivity in acidic soils (Shen et al., 2004; Bojórquez-Quintal et al., 2017; Zhang et al., 2019; Salazar-Chavarría et al., 2020).

Among all stresses caused by edaphic factors (low nitrogen, increased salinity and alkalinity, soil moisture deficit, heavy metals toxicity etc.) the strongest influence is $\mathrm{Al}$-acid stress that limits crop production all around the world because over $50 \%$ of the world's potentially arable lands are 
acidic (Liu et al., 2014). The phytotoxic capacity of $\mathrm{Al}$ is connected with its strongly negative effects on major cellular structures and homeostatic process (Vardar \& Ünal, 2007). Al toxicity targets in plant cell include structure of the cell wall, physical and chemical properties of plasma membrane, $\mathrm{Ca}^{2+}$ absorption and maintenance, ionic homeostasis, signal systems, dynamic modifications of cytoskeleton, mitosis and DNA (Panda \& Matsumoto, 2007; Smirnov \& Taran, 2013; Smirnov et al., 2014).

There is evidence that $\mathrm{Al}$ toxicity can cause excessive generation and accumulation of reactive oxygen species (ROS) with oxidative damage resulting (Yamamoto et al., 2002). ROS rapidly and without difficulty interact with major biomolecules, causing physiological disfunctions (Choudhury et al., 2013). In plant cells, the induction of ROS is one of the most important biochemical signs of $\mathrm{Al}$ toxicity (Matsumoto \& Motoda, 2012). Some genes induced by Al toxicity code antioxidant enzymes: superoxide dismutase (SOD, EC 1.15.1.1), catalase (CAT, EC 1.11.1.6), peroxidase (POD, EC 1.11.1.7) (Ferdinando et al., 2012). Many studies reported that one primary $\mathrm{Al}$ toxicity mechanism is caused by $\mathrm{Al}$ induced oxidative damages. In others it is suggested that there is a strong connection and correlation between Al-acid stress and ROS production - oxidative stress in plant tissues (Matsumoto \& Motoda, 2013).

Common buckwheat (Fagopyrum esculentum Moench.) is a traditional Ukrainian crop that has been praised as one of the most faddish green functional foods. Furthermore, the buckwheat genus (Fagopyrum Mill.) is one of the taxonomic units of plants with $\mathrm{Al}$ resistance and is of interest for investigation and understanding of $\mathrm{Al}$ resistance mechanisms of crop plants which give rise to the ability of buckwheat to accumulate $\mathrm{Al}$ in vegetative mass (Shen \& Ma, 2001).

Therefore, the purpose of our study was to study Al-induced oxidative stress markers and the reaction of the enzymatic link of the antioxidant protection system in buckwheat plants to explain the principles of crop resistance to $\mathrm{Al}$ and consider the role of elements of redox homeostasis in the resistance of buckwheat to $\mathrm{Al}$.

\section{Materials and methods}

Field experiments were conducted at the Research Agricultural Station of Institute of Plant Physiology and Genetics of National Academy of Sciences of Ukraine, Kyiv Region. Buckwheat varieties Antaria (2014 2019) and Rubra (2014-2016) were grown with minimal technology: fertilizer application before sowing $\left(\mathrm{N}_{16} \mathrm{P}_{16} \mathrm{~K}_{16}\right)$, and graminicides fluazifop-P-butyl (2014-2015) and tepraloxidim (2016-2019) before anthesis. $\mathrm{Al}$ and $\mathrm{pH}(\mathrm{KCl})$ content in soils as well as buckwheat productivity were determined.

The content of $\mathrm{Al}$ in the soil samples was determined using ICP-MS Agilent 7700x and ICP-MS Mass Hunter WorkStation (Agilent Technologies, USA) after grinding at the mill and ashing of samples $(0.400 \mathrm{~g})$ in ICP-grade $\mathrm{HNO}_{3}$ in the microwave digestion system Milestone Start D. All solutions were prepared using Type I - Ultrapure water as defined by the American Society for Testing and Materials (ASTM), as having a resistivity of $>18 \mathrm{M} \Omega$, a conductivity of $<0.056 \mu \mathrm{S} / \mathrm{cm}$ and $<50 \mathrm{ppb}$ of Total Organic Carbons (TOC). Deionized water was prepared to ASTM Type 1 specifications or better obtained in the purification system Scholar-UV Nex Up 1000 (Human Corporation, Korea). Type I water is ultrapure and used for ICP and biochemical analysis. Solutions of IV-ICPMS71A (Inorganic Ventures, USA) served as ICP calibration standard. Internal standard - 1 ppm Sc (Inorganic Ventures, USA).

The results were processed using ICP-MS Mass Hunter Software. ICP statistical analysis and correlation were carried out in MS Excel 2014, 2019 with StatPlus LE, AnalystSoft Inc., USA.

$\mathrm{Al}$ is $99 \%$ ionized in an $\mathrm{Ar}$ plasma and as a monoisotopic element. $\mathrm{Al}$ can be affected by interferences from $\mathrm{CN}$ and $\mathrm{CNH}$ in some matrices, and a high level of Mg may lead to a $26 \mathrm{MgH}$ interference. Therefore, in a multi-component environment we used He cell mode than removed interferences effectively. Detection limit in the soil and plant samples was 9.47 ppb (Fig. 1).

Plant material growth and Al-acid stress induction. Seeds of common buckwheat (Fagopyrum esculentum Moench. cv. Rubra) were germinated in the dark at $25^{\circ} \mathrm{C}$ in Petri dishes with deionized water. After two days the seedlings were transferred to pots with sterilized sand and half diluted Knop solution ( $\mathrm{pH}$ 6.5) in trays. On the 7th day, the Al-acid stress induction was produced by supplying of $50 \mu \mathrm{M}$ $\left(\mathrm{Al}_{2}\left(\mathrm{SO}_{4}\right)_{3} \times 18 \mathrm{H}_{2} \mathrm{O}\right)$ to half diluted Knop solution that did not contain phosphorus with full strength micronutrients (Zheng, 2010). Each day the solutions with $\mathrm{Al}$ were adjusted to a $4.5 \mathrm{pH}$. The experiments were conducted in controlled conditions: temperature $-25^{\circ} \mathrm{C}$, photoperiod of $16 \mathrm{~h}$ at a photosynthetic photon flux density of $\approx 200 \mu$ mol photons $\mathrm{m}^{-2} / \mathrm{s}$.

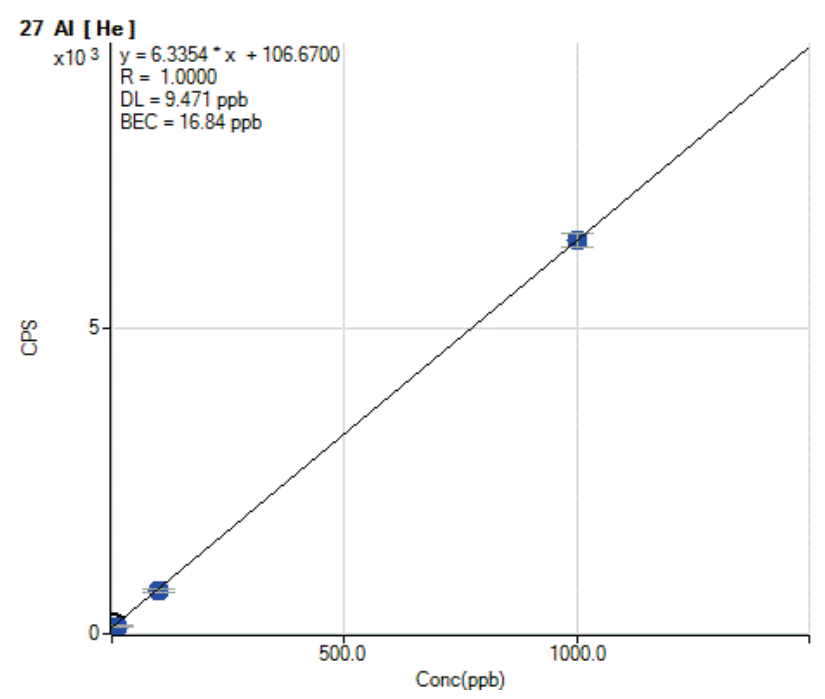

Fig. 1. Al calibration curve. Solutions of IV-ICPMS-71A (Inorganic Ventures, USA)

The extraction solvents, reagents were of P.A.-grade purity and were obtained from SynbiaS (Ukraine), Sigma-Aldrich (Germany) and Acros Organics (Belgium).

Measurement of plant growth and Al content determination in plants. On the 17th day (10 days after $\mathrm{Al}$ addition) buckwheat plants were washed in deionized water for subsequent determination of the length of the main root and shoots. Then samples were taken for chemical analysis. The content of $\mathrm{Al}$ in root and shoot tissues was measured with ICP-OES ICAP6300 Duo MEC, USA after digestion of oven-dried plant samples in ICP-grade $\mathrm{HNO}_{3}$ (Asztemborska et al., 2015).

Oxidative stress markers and antioxidant enzymes assays. For biochemical investigations, tissues of roots and leaves of control and treatment plants were used. All biochemical parameters were measured spectrophotometrically with spectrophotometer UV-1800 (Shimadzu, Japan) in dynamics on $1,2,4,6,8,10$ th days after $\mathrm{Al}$ addition. Rate of $\mathrm{O}_{2}{ }^{-}$generation was detected according to oxidation of epinephrine to adrenochrome by $\mathrm{O}_{2}^{-}$at $480 \mathrm{~nm}$ in root and leaf tissues of the buckwheat plants (Boveris, 1984). The level of lipid peroxidation was evaluated by the accumulation of thiobarbituric acid reactive substances (TBARS) (Kumar \& Knowles, 1993) with some modifications (Taran et al., 2016). Light absorption was recorded at $533 \mathrm{~nm}$. Content of TBARS was expressed in $\mu \mathrm{M}$ of malondialdehyde using a molar extinction coefficient $155 \mathrm{M} / \mathrm{cm}$.

Root and leaf tissues of buckwheat plants $(0.3 \mathrm{~g})$ were homogenized: with $1.5 \mathrm{~mL}$ of $50 \mathrm{mM}$ potassium phosphate buffer $(\mathrm{pH} 7.8), 0.1 \mathrm{mM}$ EDTA, $1 \mathrm{mM}$ PMSF for enzymes SOD and CAT; with $1.5 \mathrm{~mL}$ of $0.2 \mathrm{M}$ NaOAc buffer (pH 5.0), 0.1 mM EDTA, 1 mM PMSF for enzyme POD. The homogenates were centrifuged for $15 \mathrm{~min}$ at $12000 \mathrm{~g}$ at $4{ }^{\circ} \mathrm{C}$. The supernatants were used as source for enzymatic activities assays and protein content determination. The SOD activity was determined according to the ability of SOD to inhibit photoreduction of nitroblue tetrzolium at $560 \mathrm{~nm}$ (Giannopolitis \& Ries, 1972). The unit of SOD activity was $50 \%$ of formazan formation inhibition in the sample cuvettes. Enzyme activity was expressed in arbitrary units per milligram protein. The CAT activity was determined according to the ability of CAT to reduction of $\mathrm{H}_{2} \mathrm{O}_{2}$ at $240 \mathrm{~nm}$ (Aeby, 1984). CAT activity was calculated using a molar extinction coefficient $36 \mathrm{M} / \mathrm{cm}$. Enzyme activity was expressed in arbitrary units per milligram protein. The activity of soluble POD was determined according to $\mathrm{H}_{2} \mathrm{O}_{2}$-dependent oxidation of acidic benzidine at $530 \mathrm{~nm}$ (Zhang et al., 2011). Enzyme activity was expressed in arbitrary 
units per milligram protein. Protein content was determined using bovine serum albumin as standard (Bradford, 1976).

Experimental data are presented as the mean value of 5 to 10 independent experiments \pm the standard deviation $(\mathrm{x} \pm \mathrm{SD})$. ANOVA test was used for quantification of the parameters. Duncan's multiple range test was used to show statistical differences between means. Differences were accepted as significant for $\mathrm{P}<0.05$.

\section{Results}

In 2014-2018, the productivity of the buckwheat grown on acid soils changed significantly during the years of research (Table 1 ). The highest yields in the years of studies were obtained in fields with $\mathrm{pH}$ (salt extraction) values of soil 5.7 and 6.0, and the lowest yields - with $\mathrm{pH}$ values of 4.8 and 5.0. According to the results of 5-year studies, it was found that the correlation coefficient between soil acidity and buckwheat productivity at low nutrition backgrounds was quite high, $\mathrm{R}=-0.689 \pm 0.185$.

\section{Table 1}

Yields of buckwheat Fagopyrum esculentum Moench in years of research when cultivated on acid soils, Kyiv region $(\mathrm{s} \pm \mathrm{SD} ; \mathrm{n}=5)$

\begin{tabular}{ccc}
\hline Year & Soil pH $(1 \mathrm{M} \mathrm{KCl})$ & Yield, tha \\
\hline 2014 & 5.0 & $1.84 \pm 0.12$ \\
2015 & 5.5 & $2.02 \pm 0.11$ \\
2016 & 4.8 & $1.68 \pm 0.09$ \\
2017 & 5.7 & $2.41 \pm 0.12$ \\
2018 & 6.0 & $2.20 \pm 0.14$ \\
\hline
\end{tabular}

Note: different letters indicate the values significantly differing one from another within a line of the Table 1 on the results of comparison using the Duncan's multiple range test $(\mathrm{P}<0.05)$.

This indicates the importance of research into the mechanisms of crop resistance to increased acidity of growing soils to increase buckwheat productivity. When determining the $\mathrm{Al}$ content in the sod-podzolic soil layers it is shown that the highest $\mathrm{Al}$ content is in the clay soil substrate, at a depth of $20-40 \mathrm{~cm}$ (Table 2). In determining the content of $\mathrm{Al}$ in the root zone a tendency was established to reduce its content with changes in soil $\mathrm{pH}$ from 5.0 to 6.0 .

When assessing the development of the root system of buckwheat in the anthesis phase in the years of research it should be noted that at $\mathrm{pH} 5.0$ and below the root system was located closer to the soil surface, compared with buckwheat cultivation in the field with $\mathrm{pH}$ 6.0. In the latter variant, the root system was much better developed and reached a deeper horizon (Table 2). It is possible that these changes are part of the mechanism for the formation of crop resistance to soil acidity.

\section{Table 2}

Content of $\mathrm{Al}$ and common buckwheat root system distribution into soil profile in the sod-podzolic soil with $\mathrm{pH} 5.0$ and 6.0 of root zone, $\mathrm{BBCH} 61$, Kyiv region, 2016 (s $\pm \mathrm{SD} ; \mathrm{n}=5$ )

\begin{tabular}{ccccc}
\hline \multirow{2}{*}{$\begin{array}{c}\text { Soil profile } \\
\text { depth, } \mathrm{cm}\end{array}$} & \multicolumn{2}{c}{${ }^{27} \mathrm{Al}$ content in soil, g/kg } & \multicolumn{2}{c}{$\begin{array}{l}\text { Root system distribution by soil } \\
\text { profile, dry weight (DW) } \mathrm{g} / \mathrm{m}^{2}\end{array}$} \\
\cline { 2 - 5 } & $\mathrm{pH} 5.0$ & $\mathrm{pH} 6.0$ & $\mathrm{pH} 5.0$ & $\mathrm{pH} 6.0$ \\
\hline $0-10$ & $0.2 \pm 0.1^{\mathrm{a}}$ & $0.1 \pm 0.1^{\mathrm{a}}$ & $342 \pm 41^{\mathrm{a}}$ & $311 \pm 27^{\mathrm{a}}$ \\
$10-20$ & $3.0 \pm 0.3^{\mathrm{b}}$ & $2.8 \pm 0.5^{\mathrm{b}}$ & $29 \pm 15^{\mathrm{b}}$ & $97 \pm 21^{\mathrm{b}}$ \\
$20-40$ & $4.0 \pm 0.3^{\mathrm{bc}}$ & $4.1 \pm 0.4^{\mathrm{bc}}$ & - & - \\
\hline
\end{tabular}

Note: see Table 1.

The experimental data demonstrates inhibition of plant growth under effect of addition of $50 \mu \mathrm{M} \mathrm{Al}$ to the nutrient solution as reflected in the phenotypes of the buckwheat plants on 10th day after treatment (Fig. 2). Our results demonstrated that level of $\mathrm{Al}$ content in the root tissues increased by $55.1 \%$ (126.1 $\mu \mathrm{g} / \mathrm{g} \mathrm{DW})$, in the shoot tissues the $\mathrm{Al}$ content increased by two times ( $57.3 \mu \mathrm{g} / \mathrm{g}$ DW, Fig. 2).

The rate of $\mathrm{O}_{2}^{-}$generation was significantly increased in both parts of buckwheat plants throughout the entire period of exposure to $\mathrm{Al} 50 \mu \mathrm{M}$ in nutrient solution (Fig. 3a, b).

Analysis of the TBARS content in plant tissues shows that oxidative processes were developed in root tissues on days 2, 4 and 6 of the plants' exposure to $\mathrm{Al} 50 \mu \mathrm{M}$ in nutrient solution with a gradual reduction of TBARS level to the control value on day 10 of exposure (Fig. 3c). In leaf tissues oxidative processes were developed fractionally upon the addition $50 \mu \mathrm{M}$ Al to nutrient solution (Fig. 3d).

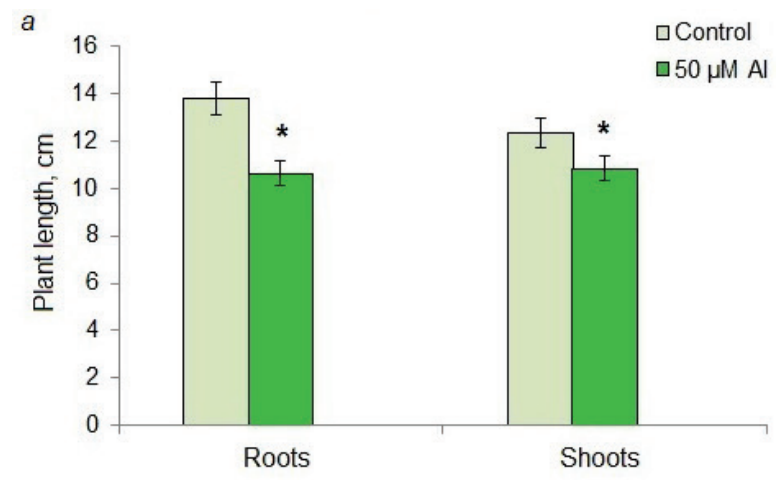

$b$
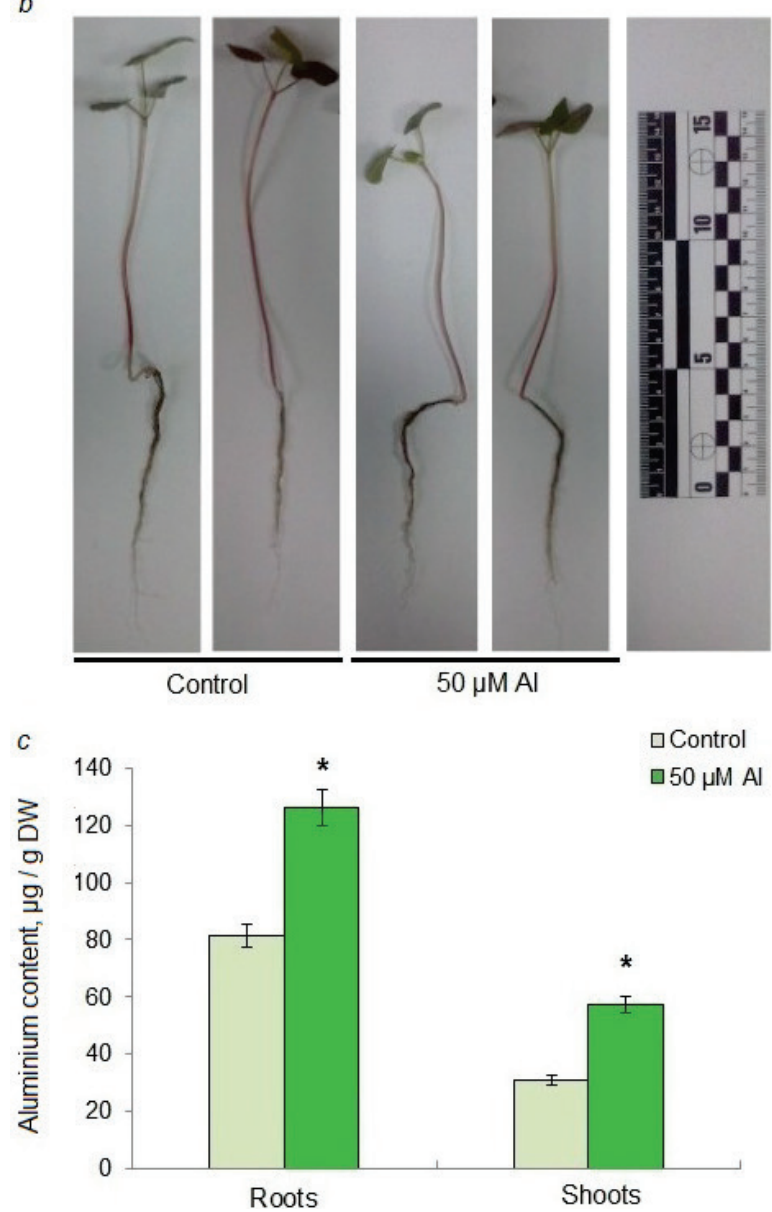

Fig. 2. Plant growth inhibition (a), phenotypes (b), and aluminium accumulation in buckwheat plant tissues $(c)$ :

*-difference significant at $\mathrm{P}<0.05(\mathrm{x} \pm \mathrm{SD} ; \mathrm{n}=10)$

The activity of SOD in leaves was significantly increased during plants' exposure to Al, especially on days 8-10 - activity level doubled (Fig. 4a). Root SOD activity in common buckwheat changed during the first 4 days, the increased level was $132.3 \%$ of control value, on days 6-10 activity of SOD reached the control level (Fig. 4b). On days 1-2 CAT activity in common buckwheat roots decreased by $27.1 \%$ and $8.4 \%$ respectively. But on further days of exposure, this tendency was altered CAT activity gradually increased - by $25.0 \%$ on day 10 (Fig. 4c). CAT activity in leaves tissues was increased on day 2 of plants' exposure to Al. The most significant elevation for common buckwheat was revealed on day 8 of exposure - by $63.8 \%$ (Fig. 4 d). Al addition did not significantly change POD activity in leaves of common buckwheat over the whole 10 days of exposure, POD activity was close to the nominal values (Fig. 4e). POD activity in roots of common buckwheat was increased by $13.5-$ $18.3 \%$ during days $2-6$ of exposure to $\mathrm{Al}$ (Fig. $4 \mathrm{f}$ ). 

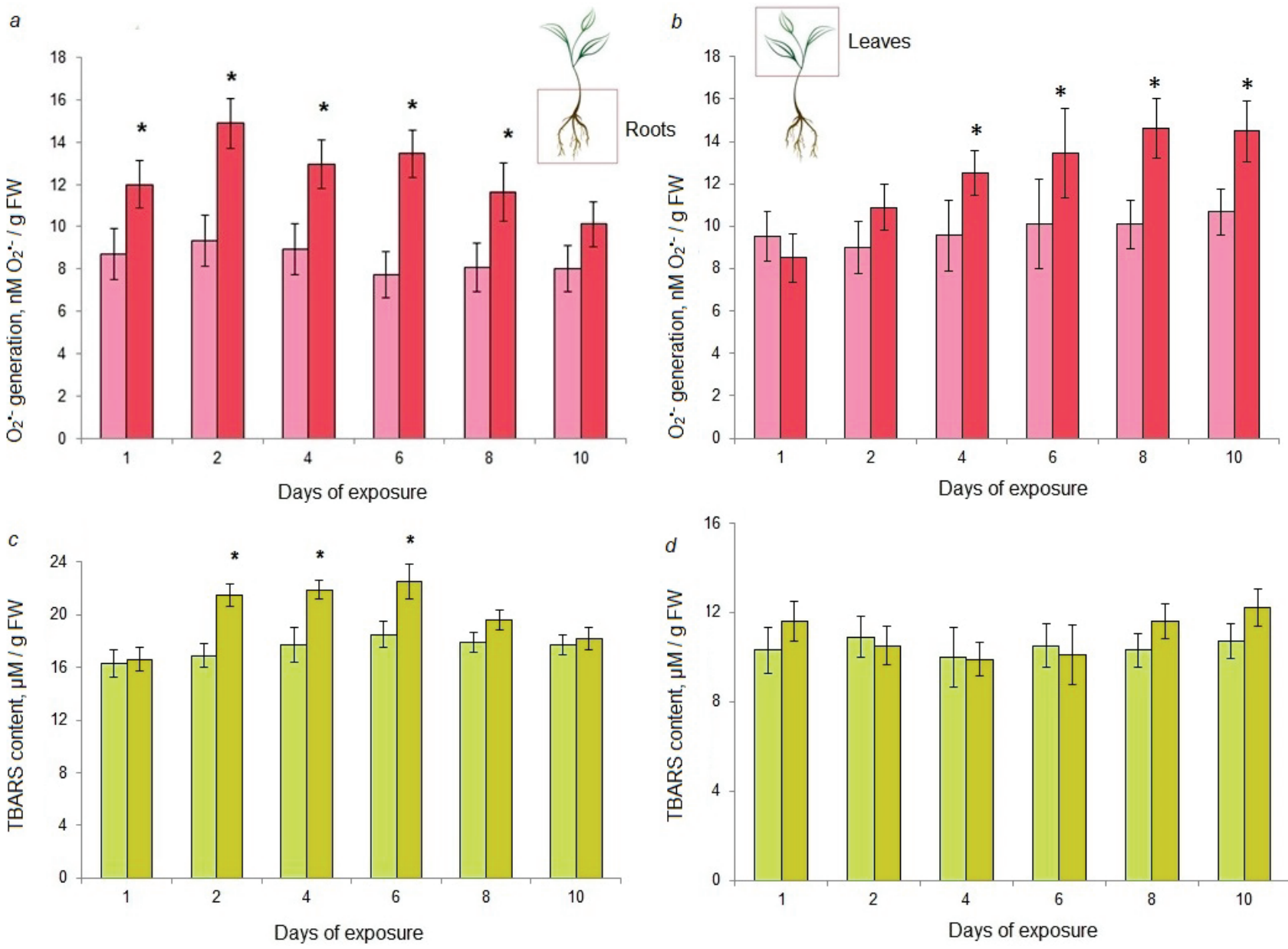

Fig. 3. Effect of aluminium exposure on prooxidant markers in buckwheat plants: $a$-generation of $\mathrm{O}_{2}{ }^{-}$in root tissues, $b$ - generation of $\mathrm{O}_{2}{ }^{-}$in leaf tissues; $c$-TBARS content in root tissues, $d$-TBARS content in leaf tissues; ${ }^{*}$ - difference significant at $\mathrm{P}<0.05(\mathrm{x} \pm \mathrm{SD} ; \mathrm{n}=5)$

\section{Discussion}

Under conditions of buckwheat cultivation on acidic soils of Polesie, its productivity changed during the years of research. With nearly identical cultivation technologies and low fertilizer doses, changes in crop productivity were largely dependent on the acidity of the soil in a particular field. The highest yields in the study years were obtained in fields with soil $\mathrm{pH}$ values of 5.7 and 6.0 , and the lowest yields were obtained with $\mathrm{pH}$ values of 4.8 and 5.0. It should be noted that buckwheat, as an early crop, suffered less from periodic droughts in the second half of vegetation during the years of the research, which contributed to unification of evaluation of reaction of culture to soil acidity.

The sufficiently high index of correlation coefficient between soil acidity and buckwheat sowing productivity allows the index of soil acidity to be classified as an important factor in determining the crop productivity.

The analysis of $\mathrm{Al}$ content in the soil profile indicates an increase in metal content in the direction from the upper root layer to the clay soil substrate. At the same time, the highest values of $\mathrm{Al}$ content in the experiment were found in the lower studied soil layers. Small differences in $\mathrm{Al}$ content between sod - podzolic soils of the region with $\mathrm{pH}$ values of 5.0 and 6.0 should be noted. At the same time, the soil with $\mathrm{pH} 6.0$ contained slightly less $\mathrm{Al}$ in the root - containing layer. It is possible that these features of the distribution of $\mathrm{Al}$ in the profile influenced the peculiarities of the root system of buckwheat plants. In the soil with $\mathrm{pH} 5.0$ most of the root system was formed closer to the surface, compared with the distribution of the root system in the soil with $\mathrm{pH}$ 6.0. Thus, in the soil profile with a $\mathrm{pH} 5.0$, only $7.8 \%$ of the total mass of dry matter of the root system was formed in a layer of 10-20 cm, and in the soil profile with a $\mathrm{pH} 6.0$ already $23.8 \%$. One should note the tendency to increase the total mass of buckwheat root system in the soil profile from $\mathrm{pH} 5.0-371 \mathrm{~g} / \mathrm{m}^{2}$, to $\mathrm{pH}$ $6.0-408 \mathrm{~g} / \mathrm{m}^{2}$. Thus, even small changes in the content of $\mathrm{Al}$ in the soil profile may be associated with the manifestation of differences in the acidity of the soil and its phytotoxicity, and determine the conditions for the formation of the root system primarily in the soil layers with the lowest accumulation of $\mathrm{Al}$.

In laboratory experiments we also established the phytotoxic effect of $\mathrm{Al}$ on buckwheat plants. One of the very early symptoms of $\mathrm{Al}$ toxicity is plant growth inhibition. Analyses of the results show that root length was decreased by $21 \%$ and shoot length - by $12 \%$. Root elongation is an indicator in tests for $\mathrm{Al}$ resistance. Afterward we observed morphological changes in aerial part of plant connected with metal ions uptake.

It was previously considered (Zheng et al., 1998) that 10 days of exposure to $50 \mu \mathrm{M} \mathrm{Al}(\mathrm{pH} 4.5)$ inhibited root growth by $65.0 \%$ in an $\mathrm{Al}$ sensitive cultivar of wheat (Triticum aestivum L.) Scout 66 and by $25.0 \%$ to $50.0 \%$ in two cultivars of oilseed rape (Brassica napus L.) 94008 and H166, two cultivars of oat (Avena sativa L.) Tochiyutaka and Heoats, and an $\mathrm{Al}$ tolerant wheat cultivar Atlas 66). It was suggested (Goh \& Lee, 1999) that $\mathrm{Al}$ related growth inhibition is the result of nutrient and water uptake disruption, interactions of $\mathrm{Al}$ ions with cell walls and plasma membranes and intake of $\mathrm{Al}$ into root symplast. Comparative analysis of literature data with our own results shows $\mathrm{Al}$ resistance of buckwheat plants.

Buckwheat is an $\mathrm{Al}$ accumulating species with strong potential for internal detoxification mechanisms after Al has entered the symplast, thence observations of $\mathrm{Al}$ induced inhibition of growth processes in whole-plants led to determination of $\mathrm{Al}$ content in root and shoot tissues.

The majority of plants and especially crop plants characterized as $\mathrm{Al}$ sensitive species with $\mathrm{Al}$ ions accumulation capacity only in the cortex of roots where endodermal cells acts as barrier to prevention following transport of $\mathrm{Al}$ to shoot tissues by xylem flux (Vitorello et al., 2005). Obtained results show accumulation of $\mathrm{Al}$ in both parts of plants after 10 days exposure to solution with $\mathrm{Al}$. Significant rise in of $\mathrm{Al}$ content in the aerial part 
of buckwheat plants confirms $\mathrm{Al}$ accumulation ability of this species as an Al resistance crop.

$\mathrm{Al}$ related oxidative damage to cell compartments and induction of ROS production is well known and described in a number of investigateons (Huang et al., 2014; Borgo et al., 2020). Nowadays the role of Al ions in redox metabolism is not particularly clarified. In Al tolerant plants even in the presence of toxic levels of Al, the levels of ROS in plant tissues do not significantly change (Daspute et al., 2017). $\mathrm{Al}$ is not a transition element and does not participate in redox reactions, but it has pro-oxidant activity promoting increased concentration of ROS and changing the redox state of the metabolic system in cells (Jaishankar et al., 2014).

Investigation of the antioxidant status of $F$. esculentum plants indicates that the addition of $\mathrm{Al}$ ions to the nutrient solution in concentration of $50 \mu \mathrm{M}$ affects the activation of generation of superoxide anion radicals,
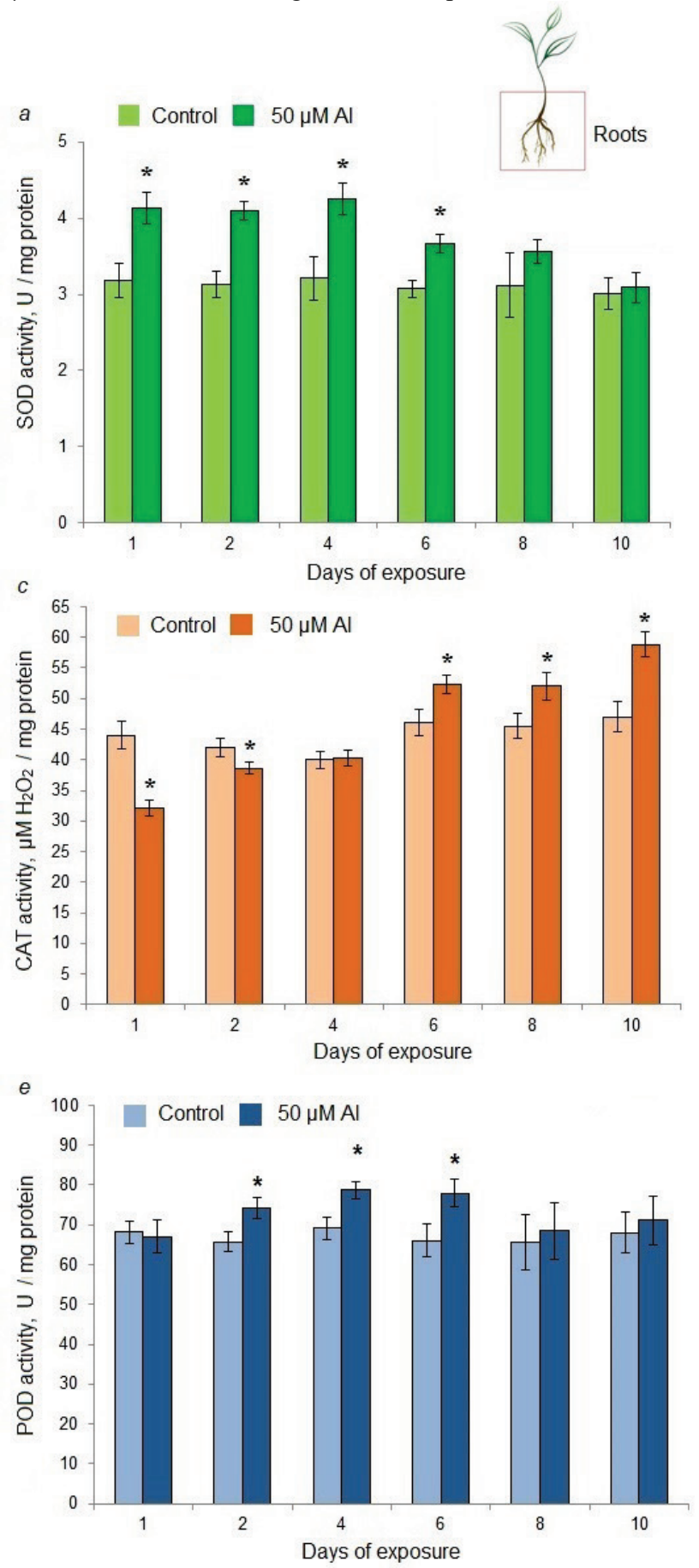

which leads to increased activity of SOD. The reaction of dismutation (neutralization) of $\mathrm{O}_{2}{ }^{-}$leads to appearance of hydrogen peroxide, which is neutralized by peroxidase, which is correlated with the recorded increase in the activity of this enzyme in root tissues (Tamas et al., 2002; Jouili et al., 2011). The increases in catalase activity depend on the time of contact of tissues of the studied plants with the toxicant. Active production of $\mathrm{H}_{2} \mathrm{O}_{2}$ increases the risk of hydroxyl radical generation, which is the most reactive form of ROS (Schopfer et al., 2002), so the excess level of hydrogen peroxide, which was not neutralized by catalase, is eliminated by nonspecific peroxidases. Gradual increase in of activities of three antioxidant enzymes involved in a chain of ROS neutralization reactions is treated as a biochemical adaptive response to Al-acid stress, which leaves the level of lipid peroxidation processes at baseline level, as evidenced by assay of markers of free radical damage of membranes (TBARS).
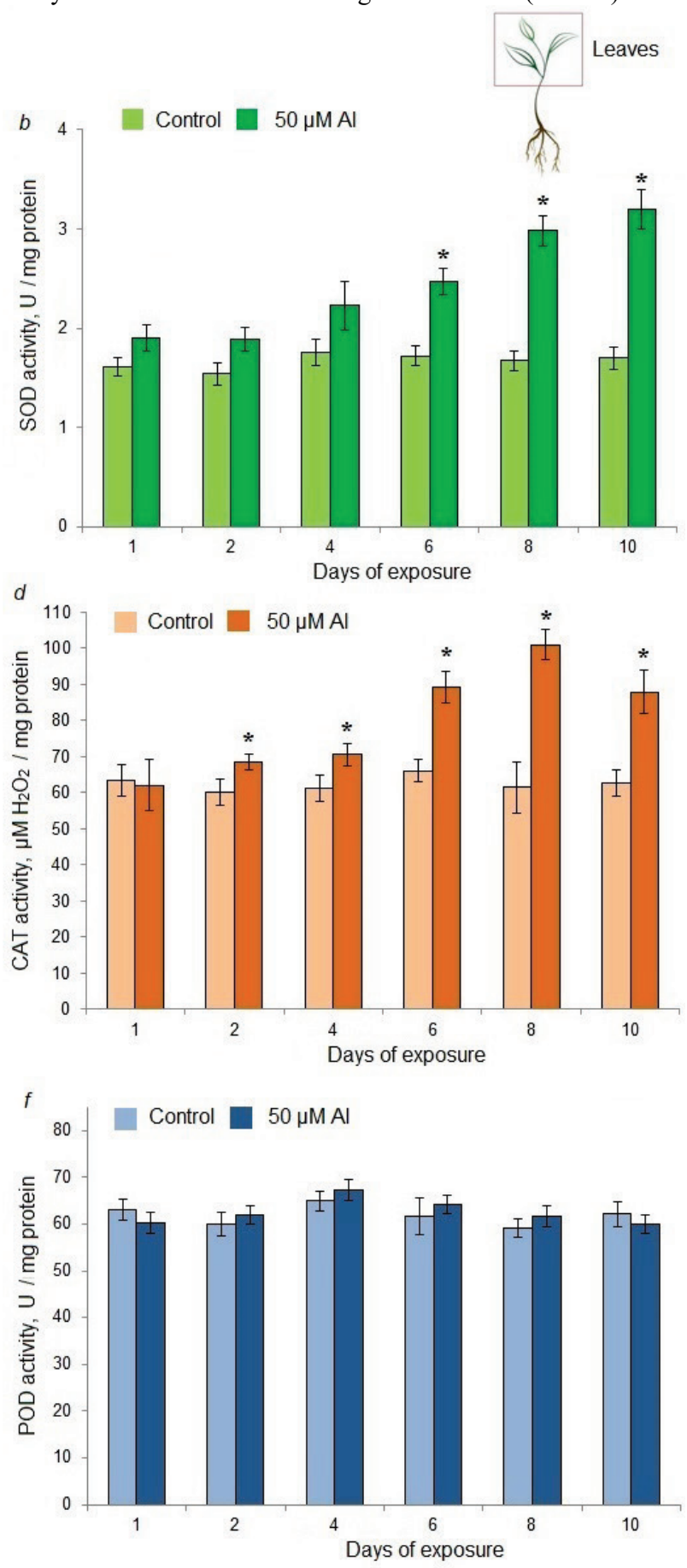

Fig. 4. Effect of aluminium exposure on antioxidant enzymes activities in buckwheat plants: $a-$ SOD in root tissues, $b-$ SOD in leaf tissues; $c$-CAT in root tissues, $d$-CAT in leaf tissues; $e-\mathrm{POD}$ in root tissues, $f$-POD in leaf tissues; ${ }^{*}$ - difference significant at $\mathrm{P}<0.05(\mathrm{x} \pm \mathrm{SD} ; \mathrm{n}=5)$ 
Therefore, the experimental data confirm the previously obtained results and indicate the development of lipid peroxidation in the root tissues only after prolonged exposure to $\mathrm{Al}$. At the same time, we noted the return of the content of TBARS to the constitutive level in root tissues of Fagopyrum esculentum at later stages of exposure. In buckwheat leaf tissues control level of TBARS products was two times lower compared to the corresponding root tissues. The addition of $50 \mu \mathrm{M} \mathrm{Al}$ to the nutrient solution did not lead to a statistically significant increase in the content of TBARS relative to control, so it can be argued that the lipid peroxidation processes in the aboveground part did not develop during the whole period of the plant's exposure to Al. The intensification of superoxide anion radical generation and the absence of products of free radical damage to lipid components of plant cells may be associated with changes in the activities of major antioxidant enzymes - superoxide dismutase, catalase and a pool of nonspecific soluble peroxidases. At the same time, buckwheat plants become more sensitive to periodic droughts of the second half of vegetation.

\section{Conclusion}

Common buckwheat is a significant culture in Ukraine, whose importance for food security has increased in recent decades. An important biological feature of buckwheat is the ability of the crop to grow on poor and especially acidic soils. Common buckwheat was sown in Ukraine on the area of 125,000 ha in 2020, mainly in the central part of the country and in soil-climatic zone Polesie in the north of the country. The yield of buckwheat on light soils of low fertility depends largely on the level of acidity of the soil. On acidic sod-podzolic soils with loam substrate, the $\mathrm{Al}$ content in the layer $20-40 \mathrm{~cm}$ is higher, compared to the layer 0-20 cm. This is probably one of the reasons why, when the concentration of $\mathrm{Al}$ in the soil profile is increased, the root system is located mainly in the upper layer of soil with a lower content of Al.

In acidic soils with $\mathrm{pH}<5.0$, phytotoxic $\mathrm{Al}^{3+}$ rapidly inhibits root growth and afterwards negatively affects water and nutrient uptake in plants. Acquiring phytotoxic capacities, in this connection $\mathrm{Al}$ ions affect a wide range of cellular and molecular processes, with a consequent reduction in plant growth. In most plant species, reactive oxygen species (ROS) production can also be induced by $\mathrm{Al}$ toxicity leading to oxidative damage of biomolecules and biological membranes. We have detected an accumulation of $\mathrm{Al}$ ions in leaf tissues of treatment plants after 10 days of exposure. Tissues of $F$. esculentum roots contained $155.4 \%$ of control level of $\mathrm{Al}$ and tissues of $F$. esculentum leaves $-186.2 \%$ of control level of $\mathrm{Al}$ ions. Significant intensification of $\mathrm{O}_{2}{ }^{-}$generation in roots and leaf tissues as a reaction to $\mathrm{Al}$ addition to nutrient solution was detected.

Increase in antioxidant enzymes activities and not fixed products of lipids peroxidation was characterized as a biochemical defense reaction of $F$. esculentum over the 10 days of exposure to $\mathrm{Al}(50 \mu \mathrm{M})$. Thus, the results show that the action of $50 \mu \mathrm{M}$ of $\mathrm{Al}$ ions activated antioxidant enzymes - SOD and CAT and decreased oxidative processes, thus promoting pro/antioxidant balance of common buckwheat plants. These mechanisms of redox homeostasis can be triggers of morphological changes in buckwheat plants, which lead to increased crop resistance when growing on acidic soils with high $\mathrm{Al}$ content. Thus, the resistance of a crop to acid soils may be related to the possibility of increased accumulation of $\mathrm{Al}$ in tissues, as well as in changes in redox homeostasis with subsequent morphological changes. Formation of the root system in the surface layer of soil with a reduced content of $\mathrm{Al}$ is an important component of the resistance of the culture to acid soils.

\section{References}

Aeby, H. (1984). Catalase in vitro. Methods in Enzymology, 105, 121-126.

Asztemborska, M., Steborowski, R., Kowalska, J., \& Bystrjewska-Piotrowska, G. (2015). Accumulation of aluminium by plants exposed to nano- and microsized particles of $\mathrm{Al}_{2} \mathrm{O}_{3}$. International Journal of Environmental Research, 9(1), 109-116

Bojórquez-Quintal, E., Escalante-Magaña, C., Echevarría-Machado, I., \& MartínezEstévez, M. (2017). Aluminum, a friend or foe of higher plants in acid soils. Frontiers in Plant Science, $8,1767$.
Borgo, L., Rabêlo, F. H., Carvalho, G., Ramires, T. G., Righetto, A. J., Piotto, F. A., Boaretto, L. F., \& Azevedo, R. A. (2020). Antioxidant performance and aluminum accumulation in two genotypes of Solanum lycopersicum in response to low $\mathrm{pH}$ and aluminum availability and under their combined stress. Scientia Horticulturae, 259, e108813.

Boveris, A. (1984). Determination of the production of superoxide radicals and hydrogen peroxide in mitochondria. Methods in Enzymology, 105, 429-435.

Bradford, M. M. (1976). A rapid and sensitive method for the quantitation of microgram quantities of protein utilizing the principle of protein-dye binding. Analytical Biochemistry, 72, 248-254.

Choudhury, S., Panda, P., Sahoo, L., \& Panda, S. (2013). Reactive oxygen species signaling in plants under abiotic stress. Plant Signaling and Behavior, 8(4), e23681.

Daspute, A. A., Sadhukhan, A., Tokizawa, M., Kobayashi, Y., Panda, S. K., \& Koyama, H. (2017). Transcriptional regulation of aluminum-tolerance genes in higher plants: Clarifying the underlying molecular mechanisms. Frontiers in Plant Science, 8,1358

FAO and WHO (2019). Sustainable healthy diets - guiding principles. Rome.

Ferdinando, M., Brunetti, C., Fini, A., \& Tattini, M. (2012). Flavonoids as antioxidants in plants under abiotic stresses. In: Ahmad, P., Prasad, M. N. V. (Eds.). Abiotic stress responses in plants: Metabolism, productivity and sustainability. Springer, New York. Pp. 159-179.

Giannopolitis, C. N., \& Ries, S. K. (1972). Superoxide dismutase I. Occurrence in higher plants. Plant Physiology, 59(2), 309-314.

Goh, C. H., \& Lee, Y. (1999). Aluminium uptake and aluminium-induced rapid root growth inhibition of rice seedlings. Journal of Plant Biology, 42, 151-158.

Haling, R. E., Simpson, R. J., Culvenor, R. A., Lambers, H., \& Richardson, A. E. (2011). Effect of soil acidity, soil strength and macropores on root growth and morphology of perennial grass species differing in acid-soil resistance. Plant, Cell and Environment, 34(3), 444456.

Huang, W., Oo, T. L., He, H., Wang, A. Q., Zhan, J., Li, C. Z., Wei, S. Q., \& He, L. F. (2014). Aluminum induces rapidly mitochondria-dependent programmed cell death in Al-sensitive peanut root tips. Botanical Studies, 55(1), 67.

Jaishankar, M., Tseten, T., Anbalagan, N., Mathew, B. B., \& Beeregowda, K. N. (2014). Toxicity, mechanism and health effects of some heavy metals. Interdisciplinary Toxicology, 7(2), 60-72.

Jouili, H., Bouazizi, H., \& Ferjani, E. E. (2011). Plant peroxidases: Biomarkers of metallic stress. Acta Physiologiae Plantarum, 33, 2075-2082.

Kumar, G. N. M., \& Knowles, N. R. (1993). Changes in lipid peroxidation and lipolitic and free-radical scavenging enzyme activities during aging and sprouting of potato (Solanum tuberosum) seed-tubers. Plant Physiology, 102, 115-124.

Liu, J., Piñeros, M. A., \& Kochian, L. V. (2014). The role of aluminum sensing and signaling in plant aluminum resistance. Journal of Integrative Plant Biology, 56(5), 221-230.

Matsumoto, H., \& Motoda, H. (2012). Aluminum toxicity recovery process in root apices. Possible association with oxidative stress. Plant Science, 185-186, 1-8.

Matsumoto, H., \& Motoda, H. (2013). Oxidative stress is associated with aluminum toxicity recovery in apex of pea root. Plant and Soil, 363, 399-410.

Ohsawa, R., Matsui, K., \& Yasui, Y. (2020). Current research and future prospects in common buckwheat (Fagopyrum esculentum). Breeding Science, 70(1), 1.

Panda, S. K., \& Matsumoto, H. (2007). Molecular physiology of aluminum toxicity and tolerance in plants. The Botanical Review, 73(4), 326-347.

Salazar-Chavarría, V., Sánchez-Nieto, S., \& Cruz-Ortega, R. (2020). Fagopyrum esculentum at early stages copes with aluminum toxicity by increasing ABA levels and antioxidant system. Plant Physiology and Biochemistry, 152, 170-176.

Schopfer, P., Liszkay, A., Bechtold, M., Frahry, G., \& Wagner A. (2002). Evidence that hydroxyl radicals mediate auxin-induced extension growth. Planta, 214, $821-828$.

Shen, R., \& Ma, J. F. (2001). Distribution and mobility of aluminium in an Al-accumulating plant, Fagopyrum esculentum Moench. Journal of Experimental Botany, 52(361), 1683-1687.

Shen, R., Iwashita, T., \& Ma, J. F. (2004). Form of Al changes with Al concentration in leaves of buckwheat. Journal of Experimental Botany, 55(394), 131-136.

Silva, S. (2012). Aluminium toxicity targets in plants. Journal of Botany, 2012, 219462

Smirnov, O. E., \& Taran, N. Y. (2013). Fitotoksychni efekty alyuminiyu ta mekhanizmy alyumorezystentnosti vyshchykh roslyn [Phytotoxic effects of aluminium and aluminium resistance mechanisms of higher plants]. Plant Physiology and Genetics, 45(4), 281-289 (in Ukrainian).

Smirnov, O. E., Kosyan, A. M., Kosyk, O. I., \& Taran, N. Y. (2014). Buckwheat stomatal traits under aluminium toxicity. Modern Phytomorphology, 6, 15-18.

Tamas, L., Huttova, J., \& Mistrik, I. (2002). Effect of aluminium on peroxidase activity in roots of Al-sensitive and Al-resistant barley cultivars. Rostlinna Vyroba, 48(2), 76-79.

Taran, N., Batsmanova, L., Kosyk, O., Smirnov, O., Kovalenko, M., Honchar, L., \& Okanenko, O. (2016). Colloidal nanomolybdenum influence upon the antioxidative reaction of chickpea plants (Cicer arietinum L.). Nanoscale Research Letters, $11,476$. 
Vardar, F., \& Ünal, M. (2007). Aluminum toxicity and resistance in higher plants. Advances in Molecular Biology, 1, 1-12.

Vitorello, V. A., Capaldi, F. R., \& Stefanuto, V. A. (2005). Recent advances in aluminium toxicity and resistance in higher plants. Brazilian of Journal Plant Physiology, 17(1), 129-143.

Yamamoto, Y., Kobayashi, Y., Devi, S. R., Rikiishi, S., \& Matsumoto, H. (2002). Aluminum toxicity is associated with mitochondrial dysfunction and the production of reactive oxygen species in plant cells. Plant Physiology, 128, 63-72.

Zhang, L., Xiao, S., Li, W., Feng, W., Li, J., Wu, Z., Gao, X., Liu, F., \& Shao, M. (2011). Overexpression of a Harpin-encoding gene hrfl in rice enhances drought tolerance. Journal of Experimental Botany, 62(12), 4229-4238.
Zhang, X., Long, Y., Huang, J., \& Xia, J. (2019). Molecular mechanisms for coping with al toxicity in plants. International Journal of Molecular Sciences, 20(7), 1551.

Zheng, S. J. (2010). Crop production on acidic soils: Overcoming aluminium toxicity and phosphorus deficiency. Annals of Botany, 106(1), 183-184.

Zheng, S. J., Ma, J. F., \& Matsumoto, H. (1998). High aluminium resistance in buckwheat. I. Al-induced specific secretion of oxalic acid from root tips. Plant Physiology, 117(3), 745-751. 